\title{
EXCESSIVE BODY WEIGHT, BODY FAT, AND EATING HABITS OF STUDENTS FROM PUBLIC AND PRIVATE
} ELEMENTARY EDUCATION *

\section{Article history:}

Received 19 February 2019

Received in revised form 1 March 2019

Accepted 3 March 2019

\section{K. B. Ferrari}

Institute of Biological and Health Sciences (ICBS), "Campus Universitário do Araguaia", "Universidade Federal de Mato Grosso" (UFMT), Pontal do Araguaia e Barra do Garças, MT, Brazil drcarlosferrari.ufmt@gmail.com

ABSTRACT - AIMS: The objective of this study was to evaluate the prevalence of excessive body weight and eating habits among students of $3^{\text {th }}$ and $4^{\text {th }}$ periods of elementary school. METHODS: 202 children ( 87 girls and 115 boys) in four schools (two publics, $\mathrm{n}=104$ and two privates, $\mathrm{n}=98$ ) from Barra do Garças (MT), Brazil were evaluated. A food frequency and physical activity questionnaire was applied. After measurement of height, weight and body mass index, the body fat (\%) was estimated using a bioimpedance scale. The estimation of frequencies and the statistical analysis were performed by the epitools ${ }^{\circledast}$ program. ResUlTs: Prevalence of both overweight and obesity were higher in private schools compared to the public ones. The prevalence of overweight ranged from $18.92 \%$ to $32.43 \%$, whereas the obesity prevalence varied from $18.2 \%$ to $36.4 \%$. Body fat distribution was highest among girls than boys. The daily dietary intake of vegetables, legumes and fruits reached only $57.4 \%, 50 \%$ and $43.6 \%$, respectively. $36.6 \%$ of the students did not drink or eat milk and its derivatives. The dietary intake of fatty foods and soft drinks 5 to 7 days per week were high, reaching $24.26 \%$ and $27.23 \%$, respectively. The weekly consumption of sweeties and candies was excessive, reaching $39.11 \%$ for 5 to 7 days. ConcLusions: obesity was higher among students from private schools and dietary intake of vegetable foods was inadequate, whereas intake of fatty foods, sweeties and soft drinks was high.

KEY W ORDS — obesity, soft drinks, sedentary lifestyle.

\section{INTRODUCTION}

Recent studies have been elucidated that childhood obesity is associated to increased risk of hypercholesterolemia, high blood pressure, non-alcoholic fatty liver disease, and metabolic syndrome in children and adolescents [1-3].

The regular use of electronic devices (tablets, smartphones, games), and the time spent watching TV, raised physical inactivity, consumption of soft and sugary drinks, sleeping problems, and the risk of obesity [4].

* Awarded work on "Congresso Multidisciplinar Integrado às Ciências da Saúde", Campinas (SP), 2017
Beyond the excessive time spent with sedentary activity, regular intake of energy and fat dense foods constitutes an important factor in determination of overweight and obesity among children and adolescents $[5,6]$.

It should be emphasized that those unhealthy lifestyles trend to perpetuate, remaining at the adult life and posing an increased risk of obesity and correlated diseases among the adults $[6,7]$.

Thus, the objective of the present study was evaluate the prevalence of excessive body weight and eating habits in students from $3^{\circ}$ and $4^{\circ}$ periods of the elementary school in two public and two private schools.

\section{METHODOLOG Y}

Population and methods

During June to August 2018, 202 children (87 girls and 115 boys), of $3^{\circ}$ and $4^{\circ}$ periods of elementary school in two public and two private schools of Barra do Garças (MT) municipality were assessed.

98 students represented public schools, whereas the remaining 104 belong to private schools in Barra do Garças, MT, Legal Amazonian region.

The heights of children were measured using a portable stadiometer (MD, Brazil). After measurement of height, body weight and total body fat were evaluated by a bioimpedance scale (Tanita, TBF-551, Japan). Values of weight and height were used to calculate body mass index $\left(\mathrm{Kg} / \mathrm{m}^{2}\right)$ of each student. In addition, a food frequency questionnaire was also applied [8].

\section{Ethical and Statistical Aspects}

Before engaging the study, participants received full explanations regarding the research and signed the informed consent term. This study is a subsample of the registered study "Epidemiology and risk factors for non-communicable diseases: development and application of a health promotion scale (HPS)" which was approved by the Research Ethics Committee of the "Campus Universitário do Araguaia da Universidade Federal de Mato Grosso (UFMT)" (protocol CAAE: 62989416.1.0000.5587-2017). The statistical analysis was performed using Epitools software (Australia). In 
order to correct, standardize and balance the samples by gender, the z-test, in two-tale mode, was applied to compare two proportions. Statistical significant differences were considered when $\mathrm{p}<0.05$.

\section{RESULTS}

The prevalence of overweight and obesity were higher in private schools compared to the public ones. The highest prevalence of obesity was found in private school 1 . The prevalence of obesity ranged from $18.92 \%$ to $32.43 \%$, whereas the prevalence of obesity varied from $18.2 \%$ to $36.4 \%$ (fig. 1 ).

The body fat distribution among girls and boys is represented in the fig. 2 .

The values of body fat distribution among boys were lower than the values found for girls. Thus, there was major prevalence of body fat values up to $25 \%$ among girls, which is considered unhealthy.

Although the weekly dietary intake of legumes, vegetables, and fruits had been considerable, only $57.4 \%, 50 \%$, and $43.6 \%$ of children got a daily ingestion of vegetables, legumes, and fruits, respectively.

The weekly consumption of refined cereals was relatively lower, once $19.3 \%$ ingested two to four times/week and $12.4 \%$ done for five or more days.

The dietary consumption of meat and its products and milk and dairy reached $82.7 \%$ and $63.4 \%$, respectively.

Furthermore, $36.6 \%$ of students did not drink milk or eat dairy foods according to nutritional recommendations. In respect of weekly dietary intake of vegetables, $42.6 \%$ of the students did not consume the adequate quantities.

The weekly ingestion of fatty foods was also elevated, since the consumption by two to four days, and by five to seven days were $37.13 \%$ e $24.26 \%$, respectively.

The dietary intake of sweeties, candies and confectionary foods was also excessive, reaching $37.13 \%$ and $39.11 \%$ for two to four days or five to seven days, respectively.

Another negative aspect was the consumption of soft drinks by the students, once the consumption of those drinks by two to four days and by five to seven days was $49.5 \%$ and $27.23 \%$, respectively.

The other aspects of food intake are presented in fig. 3 .

The leisure time physical activity practice by the students is presented in the fig. 4.

The frequency of students that did no physical activities was greatest amongst public schools compared to private ones $(\mathrm{p}<0.05)$. Notwithstanding, the majority of students $(65.91 \%)$, independent of school type, did not adequately practice physical activities to maintain health.

\section{DISCUSSION}

In the present study, the prevalence of overweight and obesity was greater in private schools compared to the public ones. Furthermore, prevalence of overweight ranged from $18.92 \%$ to $32.43 \%$, whereas the prevalence of obesity varied from $18.2 \%$ to $36.4 \%$.

Considering the ages of 8 and 9 years old, the prevalence of excessive body weight of the present study was higher even for boys than girls compared with the results found in Umuarama (PR), South Brazil, which ranged from $8.27 \%$ (overweight) to $12 \%$ (obesity) [9].

Overweight and obesity prevalence of the present study, with 8 and 9 years old students, was higher than that observed by Pinto et al. (2016) [10], with 505 students of 10 to 16 years in Ribeirão Preto (SP), Southeast Brazil. In the same manner, the prevalence of overweight and obesity was higher compared with the observed in Juiz de Fora (MG), Southeast Brazil, with a sample of 403 children, 10 to 14 years old, in which overweight and obesity were $19.9 \%$ and $10.2 \%$, respectively [11].

In a research of São Caetano do Sul (SP), with 485 children of 9 to 11 years old, authors observed greater prevalence of overweight $(45.4 \%)$ and obesity (33\%) [12] than reported in the present study.

Regarding the above mentioned studies, the prevalence of excessive body weight of the present study, realized in the inner Mato Grosso (CentralWestern Brazil), is so high than São Paulo State, the most developed of Brazil.

The distribution of body fat values among boys was lower in relation to the girls. Thus, there was higher prevalence of girls with body fat values above $25 \%$, which is considered undesirable to health.

Increased body adiposity had been inversely related to cardiorespiratory fitness amongst girls in a study with 1,223 adolescents in the city of Cascavel (PR), South Brazil [13].

At least in part the excessive body weight and adiposity could be explained by unhealthy eating habits.

Therefore, in the current work the adequate daily consumption of vegetables, legumes, and fruits was $57.4 \%, 50 \%$ and $43.6 \%$, respectively.

This consumption of vegetables and fruits of the current work was similar to that observed in 9 to 10 years old students in Coimbra (MG) Brazil [14]. However, the food consumption of the present study was higher than the observed in students of 14 to 19 years old in Sergipe (Northeast Brazil), whose unsuitability of fruits and vegetables intake reached 88.6\% [15].

Daily food consumption of meat and its products and milk and dairy was $82.7 \%$ and $63.4 \%$, respectively. The elevated meat consumption could also be ob- 


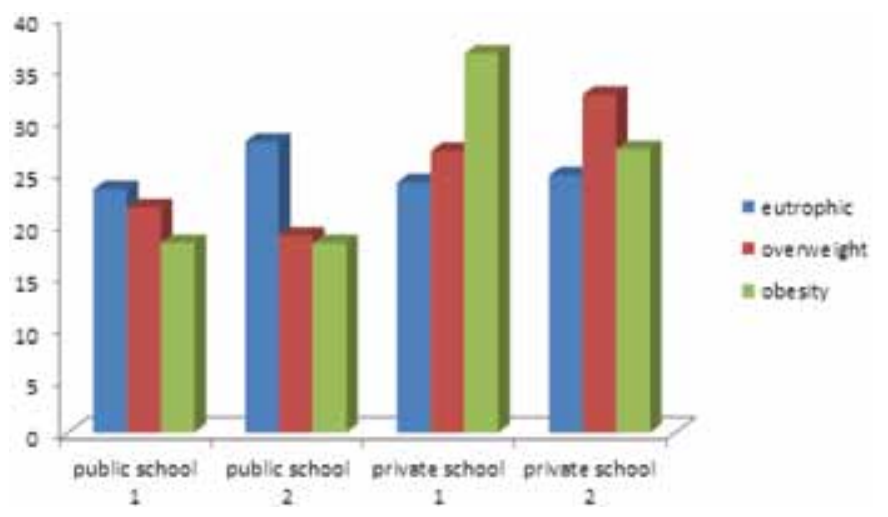

Fig. 1. Prevalence of excessive body weight among children from public and private schools of Barra do Garças (MT), Brazil

${ }^{*} a \neq b$, com $p<0.05$

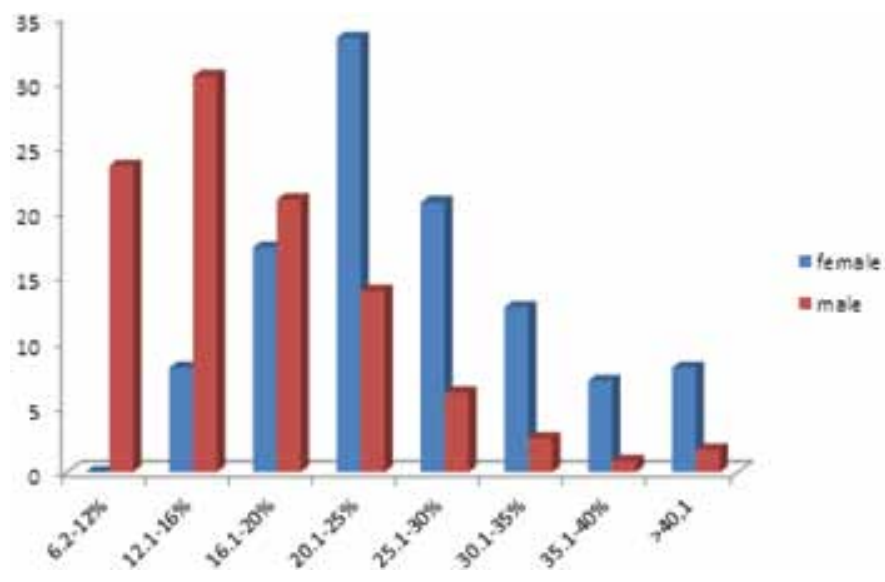

Fig. 2. Distribution of intervals of body fat, according to gender, among children from Barra do Garças (MT), Brazil

${ }^{*} p<0.04$

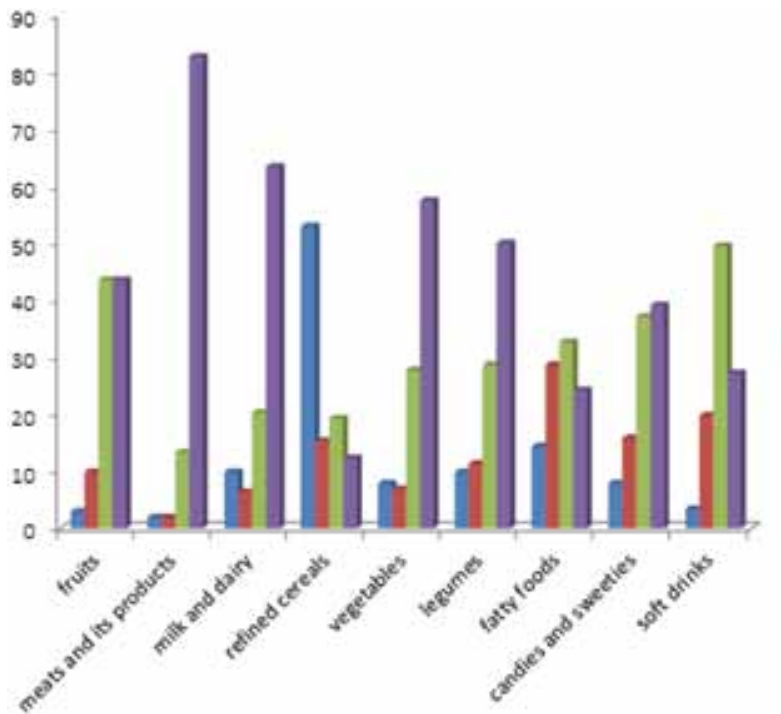

Fig. 3. Food consumption of children from Barra do Garças (MT), Brazil

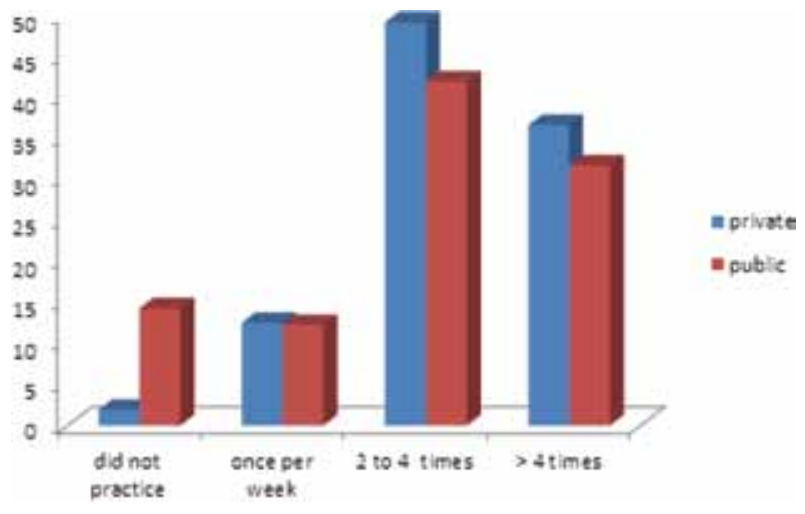

Fig. 4. Weekly frequency of practice of physical activity by students of public and private schools in Barra do Garças (MT), Brazil * Difference between groups with $p<0.05$. served in other studies with children [14-16].

Beyond that, in the current work $36.6 \%$ of the students did not drink milk or eat dairy according to nutritional recommendations. This frequency of low milk and dairy intake was major than that observed in the South Brazilian municipality Ipiranga do Sul (RS), which got $20.4 \%$ of the students in a municipal school [16].

The weekly ingestion of fatty foods was also elevated, once the consumption of two to four days and of five to seven days was $37.13 \%$ and $24.26 \%$, respectively.
Weekly consumption of sweeties, candies, and confectionary foods was also excessive, reaching $37.13 \%$ and $39.11 \%$ for two to four days, or five to seven days, respectively.

A similarly elevated consumption of sweeties, candies and confectionary foods was also reported in schoolchildren in many studies in Brazil and in India $[10,16,17]$.

A study with children and adolescents in India reported that $61.8 \%$ did not ingested leafy vegetables once a week and that the ingestion of fried foods, fatty 
foods, sweeties, processed foods, and fast foods is far higher compared to the vegetables and fish intake [17].

Another negative aspect was the drinking of soft drinks by students, since the consumption of two to four days and for five to seven days per week was $49.5 \%$ and $27.23 \%$, respectively.

A similar consumption of soft drinks was observed in children of São Paulo (Southeast Brazil) and Rio Grande do Sul (South Brazil) [10, 16], two states with highest prevalence of excessive body weight in Brazil [18].

It is known that children who regularly consume soft drinks have a major trend to consume less fruits and vegetables, practice less physical activity, and present excess of weight [15].

Notwithstanding the consumption of soft drinks which causes physiological problems in the kidney and liver, should be avoided [19].

Beyond unhealthy food habits, the time lost with sedentary activities and absence or insufficiency of regular practice of physical activity constitute other factors associated with increase of body adiposity, overweight, and obesity.

The frequency of students who did no physical activity was higher among those from public schools in relation to those from private schools. However, the majority of students, of both kinds of schools, did not practice physical activities in sufficient quantity to maintain health, which represented $65.91 \%$.

Another study realized with 89 adolescents in many schools of Barra do Garças (MT), presented similar result found in the current study, once $65 \%$ of schoolchildren had sedentary behavior [20].

The insufficiency of physical activity observed in the present study was similar to the observed in a study with students of Sergipe (Northeast Brazil), in which $71 \%$ of them did not practice the minimum of recommended of physical activity per week [15]. The prevalence of sedentary behavior amongst schoolchildren in Pelotas (RS), South Brazil, was 69.2\% [21] similar to the prevalence reported here.

In this way, a study with children demonstrated that short sleep timing, lower practice of physical exercise, and spent too much time in sedentary activities (like sitting, watching television, and using computer and electronic media) considerably enhanced the cardiometabolic risk [22].

Hortj et al. (2014) 23 demonstrated that even the time spent with sedentary activities than the lower time spent with physical activities were associated with increased risk of obesity and metabolic syndrome among 8 to 11 years old children in Denmark.

Finally, the time spent sitting was associated with increased general mortality in a study covering 54 countries [24].

\section{CONCLUSIONS}

In the current study performed in the inner Mato Grosso, at the border of Goiás State, the prevalence of both excessive body weight and sedentary behavior were very raised, whereas the intake of sweeties, candies and confectionary foods, and fried foods was also higher, there was a lower ingestion of fruits and vegetables, factors that inspire future concrete actions regarding education and health promotion to schoolchildren.

\section{REFERENCES}

1. CHEDJOU-NONO E, SAP S, CHOUKEM S-P, TETANYE IN, NEBONGO D, NDOMBO OK. Cardiometabolic profile of obese children in a subSaharan African setting: a cross-sectional study. BMC Pediatrics 2017; 17: 129. DOI: 10.1186/s12887-0170880-2.

2. DESHPANDE SR, RATHOD PG, MANKAR $S$, NARLAWAR U, UGHADE S. Systemic hypertension and pré-hypertension among school going adolescents: a cross-sectional study. J Comm Health Manag 2017; 4(1): 18-23. DOI: 10.18231/23942738.2017.0004

3. JIMENEZ-RIVERA C, HADIIYANNAKIS S, DAVILA J, HURTEAU J, AGLIPAY M. BARROWMAN N, ADAMO KB. Prevalence and risk factors for non-alcoholic fatty liver disease in children and youth with obesity. BMC Pediatr 2017; 17:113. DOI: $10.1186 / s 12887-017-086-z$.

4. KENNEY EL, GORTMAKER SL. United States adolescents' television, computer, videogame, smartphone, and tablet use: associations with sugary drinks, sleep, physical activity, and obesity. J Pediatr 2017; 182: 144-9. DOI: https://doi.org/10.1016/j. jpeds.2016.11.015

5. GHONGE $S$, BHAMBHANI GD, ADHAV PS, THAKOR N. Determinants of obesity and overweight among school chindren of Pune city, Maharashtra, India: a cross sectional study. Int $J$ Res Med Sci 2015; 3(12): 3638-43. DOI: http://dx.doi. org/10.18203/2320-6012.ijrms20151415

6. LITTLE M, HUMPHRIES S, PATEL K, DEWEY C. Factors associated with BMI, underweight, overweight, and obesity among adults in a population of rural south India: a cross-sectional study. BMC Obesity 2016; 3: 12. DOI: 10.1186/s40608-016-0091-7.

7. SPANHOL RC, FERRARI CKB. Obesity and lifestyle risk factors among an adult population in Legal Amazon, Mato Grosso, Brazil. Rev Salud Pública 2016; 18(1):26-36. DOI: https://doi.org/10.15446/ rsap.v18n1.30570

8. VIEIRA VCR, PRIORE SE, RIBEIRO SMR, FRANCESCHINI SCC, ALMEIDA LP. Socioeconomic, nutritional and health profile of adolescents recently admitted to a Brazilian public university. Rev Nutr 2002;15: 273-82. http://dx.doi.org/10.1590/ S1415-52732002000300003 
9. CARVALHO ARM DE, BELÉM MO, ODA JY. Sobrepeso e obesidade em alunos de 6-10 anos de escola estadual em Umuarama/PR. Arq Ciênc Saúde Unipar 2017; 21(1): 3-12. http://www.revistas.unipar. br/index.php/saude/article/viewFile/6070/3389

10. PINTO RP, NUNES AA, MELLO LM DE. Análise dos fatores associados ao excesso de peso em escolares. Rev Paul Pediatr 2016; 34(4): 460-8. DOI: https://doi. org/10.25110/arqsaude.v21i1.2017.6070

11. OLIVEIRA PM DE, SILVA FA DA, OLIVEIRA RMS, MENDES LL, NETTO MP, CÂNDIDO APC. Associação entre índice de massa de gordura e índice de massa livre de gordura e risco cardiovascular em adolescentes. Rev Paul Pediatr 2016; 34(1): 30-7. http://dx.doi.org/10.1016/j.rppede.2015.06.020

12. MATSUDO VKR, FERRARI GLM, ARAÚJO TL, OLIVEIRA LC, MIRE E, BARREIRA TV, TUDOR-LOCKE C, KATZMARZYK P. Socioeconomic status indicators, physical activity, and overweight/obesity in Brazilian children. Rev Paul Pediatr 2016; 34(2): 162-70. http://dx.doi.org/10.1016/j. rppede.2015.08.018

13. MINATTO G, SOUSA TF DE, CARVALHO WRG DE, RIBEIRO RR, SANTOS KD, PETROSKI EL. Relação entre aptidão cardiorrespiratória e adiposidade corporal em meninas. Rev Paul Pediatr 2016; 34(4): 469-75. http://dx.doi.org/10.1016/j. rppede.2016.02.014

14. ALMEIDA ICO, NAVARRO F. Caracterização do estado nutricional, atividade física e alimentação de escolares entre 9 e 10 anos da rede pública de ensino de Coimbra-MG. Rev Bras Nutr Esp 2017; 11(63): 327 38. http://www.rbne.com.br/index.php/rbne/article/ view/805/637

15. SILVA FMA, SMITH-MENEZES A, DUARTE MFS. Consumo e frutas e vegetais associado a outros comportamentos de risco em adolescentes no Nordeste do Brasil. Rev Paul Pediatr 2016; 34(3): 309-15. http://dx.doi.org/10.1016/j.rppede.2015.09.004

16. COLEONE JD, KÜMPEL DA, ALVES ALS'A, MATTOS CB. Perfil nutricional e alimentar de escolares matriculados em uma escola municipal. Ciênc Saúde 2017; 10(1): 34-8. http://dx.doi. org/10.15448/1983-652X.2017.1.22762

17. GHOSH, A., DUTTA, R. Food habits and body composition in children and adolescents of Asian Indian origin. Nutr Metab Cardiovasc Dis, v.20, p.e5, 2010 DOI: https://doi.org/10.1016/j.numecd.2009.04.016

18. GUIMARÃES-JR MS, FRAGA AS, ARAÚJO TB, TENÓRIO MCC. Fator de risco cardiovascular: a obesidade entre crianças e adolescentes nas macrorregiões brasileiras. Rev Bras Obes Nutr Emagrecim 2018;12(69):132-42. http://www.rbone.com.br/ index.php/rbone/article/view/670/517

19. ALKHEDAIDE A, SOLIMAN MM, SALAH ELDIN A-E, ISMAIL TA, ALSHEHIRI ZS, ATTIA HF. Chronic effects of soft drink consumption on the health state of Wistar rats: A biochemical, genetic and histopathological study. Mol Med Rep 2016; 13: 5109 17. https://doi.org/10.3892/mmr.2016.5199
20. FERRARI CKB, CARNEIRO SS, ROCHA EM, SANTOS ALV. Sedentarismo, estilo de vida e saúde em adolescentes de um município da Amazônia Legal. Rev Inspirar Mov Saúde 2017;14(3):28-33. https:// www.inspirar.com.br/wp-content/uploads/2017/07/ revista-inspirar-ms-43-536-2016.pdf

21. FERREIRA RW, ROMBALDI AJ, RICARDO LIC, HALLAL PC, AZEVEDO MR. Prevalência de comportamento sedentário de escolares e fatores associados. Rev Paul Pediatr 2016; 34(1): 56-63. http:// dx.doi.org/10.1016/j.rppede.2015.09.002

22. COLWELL CS, MATVEYENKO AV. Timing is everything: implications for metabolic consequences of sleep restriction. Diabetes 2014;63:1826-8. https:// dx.doi.org/10.2337\%2Fdb14-0283

23. HORTJ MF, CHAPUT J-P, DAMSGAARD CT, DALSKOV S-M. ANDERSEN R, ASTRUP A, MICHAELSEN KF, TETENS I, RITZ C, SJÖDIN A. Low physical activity level and short sleep duration are associated with an increased cardio-metabolic risk profile: A longitudinal study in 8-11 year old Danish Children. PLoS ONE 2014; 9(8): e104677. DOI: 10.1371/journal.pone.0104677

24. REZENDE LFM ET AL. All-cause mortality attributable to sitting time. Analysis of 54 countries worldwide. Am J Prev Med 2016; 51(2): 253-63. https:// doi.org/10.1016/j.amepre.2016.01.022 